\title{
Isotopic composition and elemental concentrations in groundwater in the Kuiseb Basin and the Cuvelai-Etosha Basin, Namibia
}

\author{
Nnenesi A. Kgabi ${ }^{1}$, Eliot Atekwana ${ }^{2}$, Johanna Ithindi ${ }^{1}$, Martha Uugwanga ${ }^{1}$, Kay Knoeller ${ }^{3}$, \\ Lebogang Motsei ${ }^{4}$, Manny Mathuthu ${ }^{5}$, Gideon Kalumbu ${ }^{1}$, Hilma R. Amwele ${ }^{6}$, and Rian Uusizi ${ }^{1}$ \\ ${ }^{1}$ Department of Civil and Environmental Engineering, Namibia University \\ of Science and Technology, Windhoek, Namibia \\ ${ }^{2}$ Department of Geological Sciences, University of Delaware, Newark, Delaware, USA \\ ${ }^{3}$ Department of Catchment Hydrology, Helmholtz Centre for Environmental Research, Leipzig, Germany \\ ${ }^{4}$ School of Agriculture, North-West University, Mafikeng, South Africa \\ ${ }^{5}$ Centre for Applied Radiation Science and Technology, North-West University, Mafikeng, South Africa \\ ${ }^{6}$ Department of Agriculture \& Natural Resources Sciences, Namibia University \\ of Science and Technology, Windhoek, Namibia
}

Correspondence: Nnenesi A. Kgabi (nkgabi@nust.na)

Received: 11 November 2017 - Revised: 25 February 2018 - Accepted: 5 March 2018 - Published: 29 May 2018

\begin{abstract}
We assessed environmental tracers in groundwater in two contrasting basins in Namibia; the Kuiseb Basin, which is a predominantly dry area and the Cuvelai-Etosha Basin, which is prone to alternating floods and droughts. We aimed to determine why the quality of groundwater was different in these two basins which occur in an arid environment. We analysed groundwater and surface water for the stable isotope ratios of hydrogen $\left(\delta^{2} \mathrm{H}\right)$ and oxygen $\left(\delta^{18} \mathrm{O}\right)$ by cavity ring-down spectroscopy and metals by inductively coupled plasma mass spectrometry. The $\delta^{2} \mathrm{H}$ and $\delta^{18} \mathrm{O}$ of surface water in the Cuvelai-Etosha Basin plot on an evaporation trend below the global meteoric water line (GMWL) and the local meteoric water line (LMWL). The $\delta^{2} \mathrm{H}$ and $\delta^{18} \mathrm{O}$ of some groundwater samples in the Cuvelai-Etosha Basin also plot on the evaporation trend, indicating recharge by evaporated rain or evaporated surface water. In contrast, the $\delta^{2} \mathrm{H}$ and $\delta^{18} \mathrm{O}$ of groundwater samples in the Kuiseb Basin plot mostly along the GMWL and the LMWL, indicating direct recharge from unevaporated rain or unevaporated surface water. Fifty percent of groundwater samples in the Cuvelai-Etosha Basin was potable (salinity < 1 ppt) compared to $79 \%$ in the Kuiseb Basin. The high salinity in the groundwater of the CuvelaiEtosha Basin does not appear to be caused by evaporation of water (evapo-concentration) on surface prior to groundwater recharge, but rather by the weathering of the Kalahari sediments. The low salinity in the Kuiseb Basin derives from rapid recharge of groundwater by unevaporated rain and limited weathering of the crystalline rocks. The order of abundance of cations in the Kuiseb Basin is $\mathrm{Na}>\mathrm{K}>\mathrm{Ca}>\mathrm{Mg}$ vs. $\mathrm{Na}>\mathrm{Mg}>\mathrm{Ca}>\mathrm{K}$ for the Cuvelai-Etosha Basin. For metals in the Kuiseb Basin the order of abundance is $\mathrm{Fe}>\mathrm{Al}>\mathrm{V}>\mathrm{As}>\mathrm{Zn}$ vs. $\mathrm{Al}>\mathrm{Fe}>\mathrm{V}>\mathrm{As}>\mathrm{Zn}$ for the Cuvelai-Etosha Basin. The relative abundance of cations and metals are attributed to the differences in geology of the basins and the extent of water-rock interaction. Our results show that the quality of groundwater in Cuvelai-Etosha Basin and Kuiseb Basin which vary in the extent of aridity, is controlled by the extent of water-rock interaction at the surface and in the groundwater aquifer.
\end{abstract}




\section{Introduction}

Water scarcity is one of the key limiting factors to sustainable economic, industrial, social and environmental development. In addition to scarcity, quality is a limiting factor for the sustainable use of water for domestic, agricultural and industry activities. For example, salinization which impairs the use of water is a global problem. Moreover, salinization is more severe in arid regions, where groundwater is the primary source of water (IAEA, 2006).

In arid environments, precipitation and groundwater recharge are extremely variable (Lewis and Walker, 2002). The spatial variability of rain recharge along permanent and intermittent river reaches and the variable water-rock interaction and groundwater mixing add complexity to investigating the origin and chemical evolution of groundwater. The source(s) of water and the physical and chemical evolution can be assessed by environmental tracers such as isotopes and the types of chemical constituents (e.g., major and trace elements) (Elliot, 2014). For example, the stable hydrogen $\left(\delta^{2} \mathrm{H}\right)$ and oxygen $\left(\delta^{18} \mathrm{O}\right)$ isotopic composition of groundwater depends on that of precipitation. However, the climatic conditions of the recharge environment and other local factors such as topography and the recharge process can cause variation in the $\delta^{2} \mathrm{H}$ and $\delta^{18} \mathrm{O}$ which can be traced in groundwater (Fritz et al., 1987; Clark and Fritz, 1997).

Namibia, located in an arid climate is becoming more dependent on groundwater, especially during droughts. The quality of the groundwater obtained from different groundwater basins are highly variable. In general, groundwater conditions are unfavourable due to limited availability, little and unreliable recharge, low borehole yields, poor groundwater quality and high risks of contamination (Christelis and Struckmeier, 2011). It is therefore important to assess groundwater in order to understand the factors that cause variability in the quality. In this study, we use environmental tracers to assess the nature of recharge and control of the quality of groundwater in the Kuiseb Basin and Cuvelai-Etosha Basin. Potential evapotranspiration in the Kuiseb Basin (785-1241 $\mathrm{mm} \mathrm{yr}^{-1}$ ) and Cuvelai-Etosha Basin (1880-2173 $\mathrm{mm} \mathrm{yr}^{-1}$ ) are variable (Kaseke et al., 2016). On an annual basis, the rainfall frequencies and intensity vary significantly in the Kuiseb Basin $\left(8-255 \mathrm{~mm} \mathrm{yr}^{-1}\right)$ and Cuvelai-Etosha Basin (410-690 $\mathrm{mm} \mathrm{yr}^{-1}$ ) (e.g., Kaseke et al., 2016), which determines how rain is affected prior to recharge of groundwater. In the Kuiseb Basin, there is limited surface ponding and runoff and the basin is predominantly dry. In contrast, the Cuvelai-Etosha Basin is prone to alternating floods and droughts and water ponds periodically on the surface and there is intermittent river flow during flood periods. In the Kuiseb Basin, the quality of groundwater although portable is highly variable across the basin while in the Cuvelai-Etosha Basin, groundwater quality is mostly poor due to high salinity (Falke, 2008).

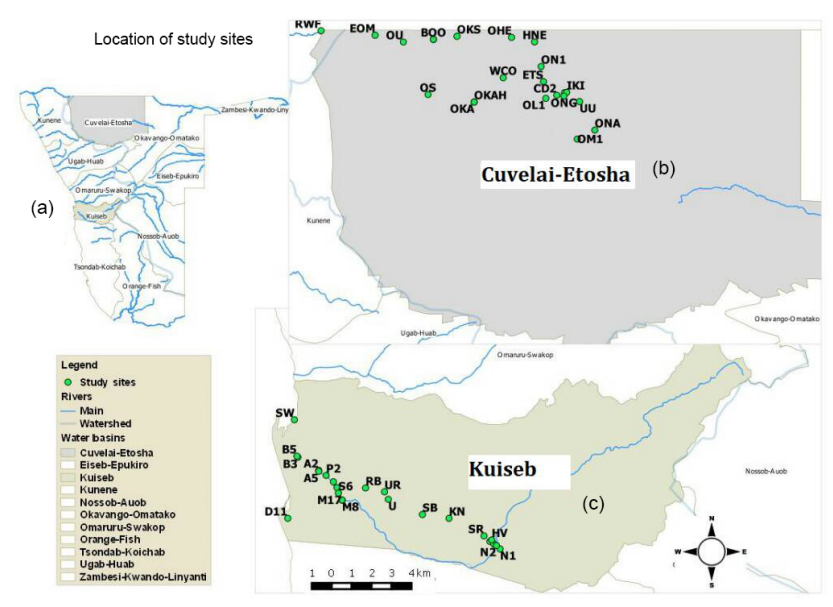

Figure 1. Map of Namibia showing the drainage basins (a) and sampling station for the Cuvelai-Etosha Basin (b) and the Kuiseb Basin (c).

\section{Study Area}

The Kuiseb Basin is located in the western part of Namibia (Fig. 1) within the Namib Desert that stretches parallel to the coast.

The Kuiseb Basin is underlain by a crystalline basement of metamorphic sedimentary rocks (schist, quartzite or marble) with granitic intrusions (Miller, 1980; Schneider, 2004) and sediments derived from these rocks. The Kuiseb Basin is divided into an upper watershed which consists of highlands and commercial farms, a middle watershed which has the Namib-Naukluft Park and small-scale farms (predominantly Topnaar communities) and a lower watershed close to the coast encompassing the Walvis Bay and surrounding area. The Basin is drained by the Kuiseb River (Falke, 2008) and flows only after extremely heavy rains such as in 2011 (Mendelson et al., 2013; Gardiner et al., 2006). The two aquifers in the Kuiseb Basin are located at Swartbank and Rooibank in the lower portion of the basin. Groundwater in the Kuiseb Basin is recharged exclusively from rainfall and runoff (Heyns and van Vuuren, 2009).

The Cuvelai-Etosha Basin is located in the north-central part of Namibia. The Cuvelai-Etosha Basin is covered by limestone and dolomite rocks and Kalahari sediments (unconsolidated to semi-consolidated sands, gravels and silts and calcrete) (Mendelson et al., 2013). Groundwater in the basin is mainly abstracted from the Ohangwena Kalahari Aquifer and discontinuous perched aquifers by means of boreholes. Wells are used to supply water, especially to isolated villages in the basin (Hamukoto et al., 2017). The groundwater is saline except for the Tsumeb Karst. 


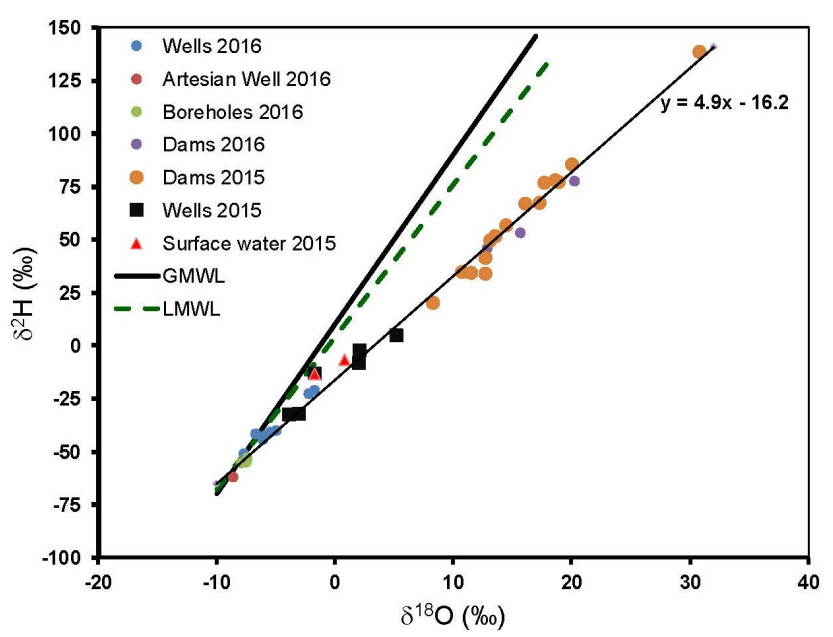

Figure 2. Plot of the stable oxygen isotopes $\left(\delta^{18} \mathrm{O}\right)$ vs. hydrogen $\left(\delta^{2} \mathrm{H}\right)$ for water samples from the Cuvelai-Etosha Basin. GMWL is the global meteoric water line and LMWL is the local meteoric water line.

\section{Methods}

We collected and analysed water samples from groundwater and surface water in August to November of 2015 and in August to September 2016. Fifty-six sampling points were investigated; 25 sampling points from the Cuvelai-Etosha Basin and 31 from the Kuiseb Basin.

Groundwater samples were collected from wells (hand dug) and boreholes. The groundwater was pumped to the surface for about $5 \mathrm{~min}$ to obtain water from the formation. Surface water was sampled by the grab techniques along rivers and dams. An artesian groundwater was sampled where it issued to the surface. All water for cations and anions were collected in polyethylene bottles and stored in cooler boxes. The samples were filtered in the laboratory and refrigerated until analyses. Water for stable isotopes were collected in glass vials, kept cool in the field and refrigerated in the laboratory until analyses.

Water temperature was measured onsite and the total dissolved solids (TDS), salinity and electrical conductivity were measured either onsite using a portable HQ40d Dual Input Multi-parameter instrument or in the laboratory using microelectrodes. Elemental concentrations were determined by EPA Method 200.8 using an inductively coupled plasma mass spectrometry (NexION 300D/350D) as described by Pruszkowski and Bosnak (2014). Water analysed for $\delta^{2} \mathrm{H}$ and $\delta^{18} \mathrm{O}$ was done by Cavity Ring-Down Spectrometry (Picarro L2120-i) and are reported in the standard delta $(\delta)$ notation in per mil (\%o) relative to the VSMOW for the $\mathrm{H}$ and $\mathrm{O}$ isotopes.

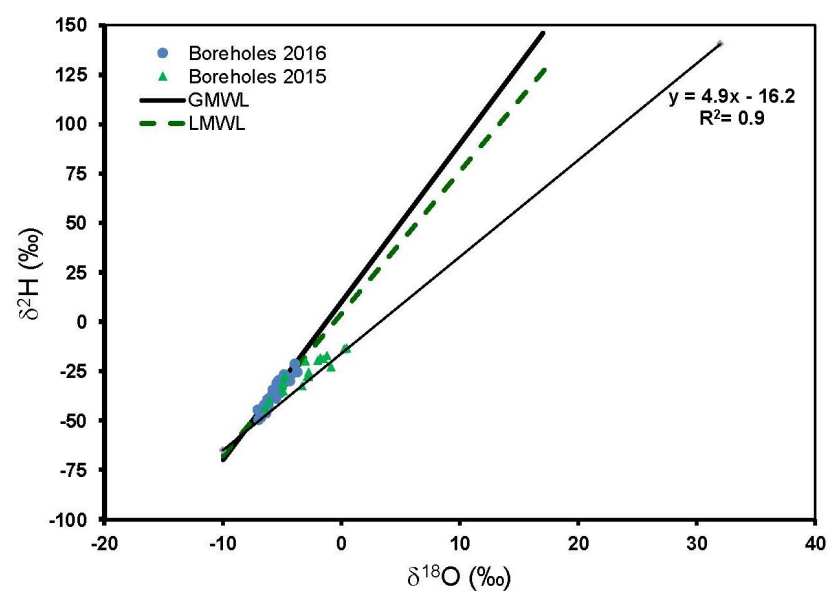

Figure 3. Plot of the stable oxygen isotopes $\left(\delta^{18} \mathrm{O}\right)$ vs. hydrogen $\left(\delta^{2} \mathrm{H}\right)$ for water samples from the Kuiseb Basin. GMWL is the global meteoric water line and LMWL is the local meteoric water line.

\section{Results and Discussion}

\subsection{Isotope Ratios}

The $\delta^{2} \mathrm{H}$ and $\delta^{18} \mathrm{O}$ from the Cuvelai-Etosha Basin and the GMWL (Craig, 1961) and LMWL $\left(\delta^{2} \mathrm{H}=7.2 \delta^{18} \mathrm{O}+4.1\right.$; Turewicz, 2013) are shown in Fig. 2.

The $\delta^{2} \mathrm{H}$ and $\delta^{18} \mathrm{O}$ of surface waters are enriched and plot along a line below the GMWL and the LMWL, reflecting high evaporation. Some groundwater samples lie along the evaporation line and were subject to evaporation prior to groundwater recharge (Prada et al., 2010).

The $\delta^{2} \mathrm{H}$ and $\delta^{18} \mathrm{O}$ from the Kuiseb Basin are shown in Fig. 3. Also shown are the GMWL and the LMWL. Compared to the Cuvelai-Etosha Basin, groundwater in the Kuiseb Basin were more depleted and the $\delta^{2} \mathrm{H}$ and $\delta^{18} \mathrm{O}$ plot mostly along the GMWL and the LMWL and at the lower end of the evaporation line.

In principle, the $\delta^{2} \mathrm{H}$ and $\delta^{18} \mathrm{O}$ of groundwater should be related to that of the local precipitation. The $\delta^{2} \mathrm{H}$ and $\delta^{18} \mathrm{O}$ of groundwater co-vary, and on a global basis lie on the GMWL or on the LMWL (e.g., Clark and Fritz, 1997). The GMWL and the LMWL have been used in various studies as a convenient reference for tracing the origin and evolution of water in the hydrologic cycle (McGuire and McDonnel, 2007). When the rain or surface water is subjected to evaporation, the covariation between the $\delta^{2} \mathrm{H}$ and $\delta^{18} \mathrm{O}$ deviate and lie below the GMWL and LMWL; the extent of the deviation depends on the aridity.

In a study of the distribution of $\delta^{2} \mathrm{H}$ and $\delta^{18} \mathrm{O}$ in rain across Namibia, Kaseke et al. (2016) modelled heavier $\delta^{2} \mathrm{H}$ and $\delta^{18} \mathrm{O}$ for rains in the Kuiseb Basin and more depleted values for rains in the Cuvelai-Etosha Basin. Yet, the $\delta^{2} \mathrm{H}$ and $\delta^{18} \mathrm{O}$ in groundwater in the Cuvelai-Etosha Basin (Fig. 2) are more enriched compared to those of groundwater the Kuiseb 


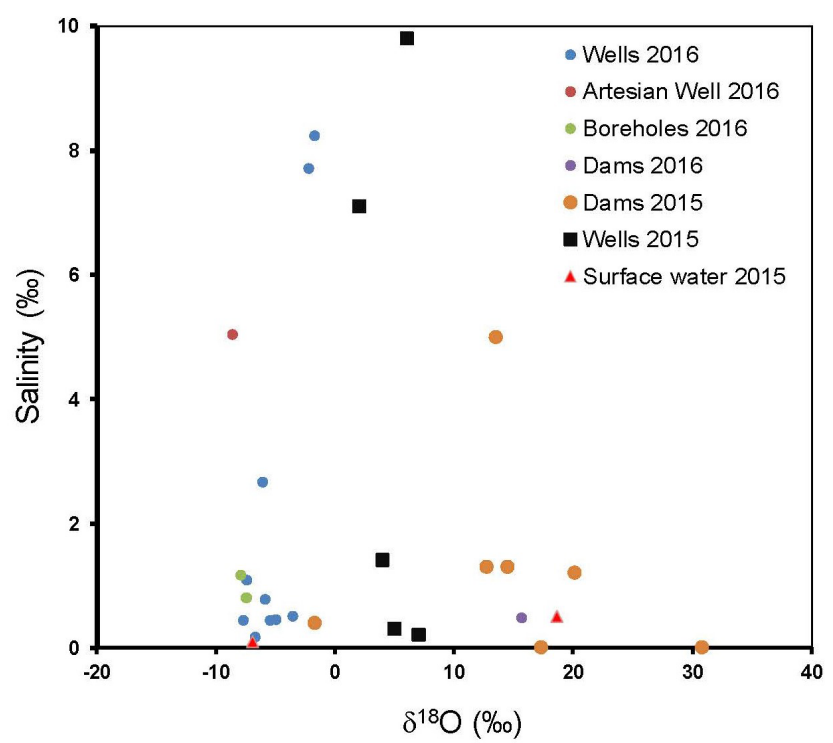

Figure 4. Plot of the stable oxygen isotopes $\left(\delta^{18} \mathrm{O}\right)$ vs. salinity for water samples from the Cuvelai-Etosha Basin.

Basin (Fig. 3). The $\delta^{2} \mathrm{H}$ and $\delta^{18} \mathrm{O}$ in some groundwater in the Cuvelai-Etosha Basin indicates extensive evaporation before groundwater recharge. This is because rainwater is trapped on the surface during flooding by muddy sediments deposited by floods which reduce rapid infiltration (Mendelson et al., 2013). This extensive evaporation of rain prior to groundwater recharge appears to be limited in the Kuiseb Basin (Fig. 3).

\subsection{Groundwater Quality}

The salinity of groundwater can be used as a proxy for the ionic content (similar to the electrical conductivity and TDS) and reflect processes that increase the solute content in water. The salinity levels in groundwater in Cuvelai-Etosha Basin are generally high (e.g., Fig. 4). About $50 \%$ of the groundwater have salinity lower than marginal $(<1 \%$ ) quality and $50 \%$ have salinity that makes the groundwater brackish to saline (1-10\%o) quality.

The salinity levels measured for the Kuiseb Basin are much lower (e.g., Fig. 5) compared to groundwater in the Cuvelia-Etosha Basin. About $79 \%$ of groundwater in the Kuiseb have salinity lower than marginal $(<1 \%$ ) quality and $21 \%$ have salinity that makes the groundwater brackish to saline (1-10\%o) quality. The high salinity levels in the Cuvelai-Etosha Basin may be due to the weathering of abundant limestone, dolomite and calcrete (Msangi, 2014). Also, high evaporation rates indicated by the enriched $\delta^{2} \mathrm{H}$ and $\delta^{18} \mathrm{O}$ of some groundwater samples point to evapoconcentration of solutes (Harbeck, 1955). Therefore, the lower salinity levels in the Kuiseb Basin may thus reflect limited weathering of the crystalline basement rocks and

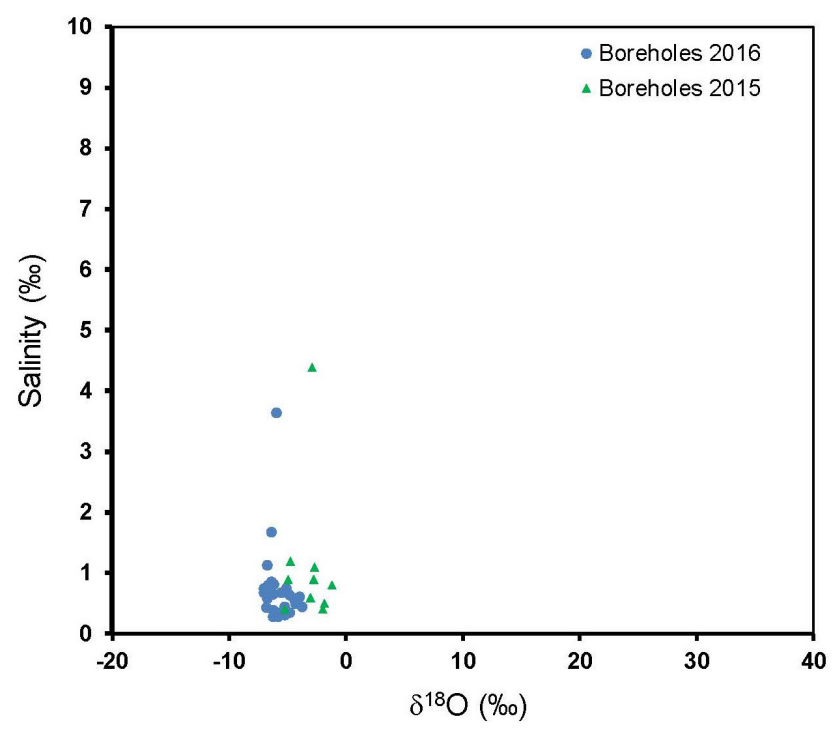

Figure 5. Plot of the stable oxygen isotopes $\left(\delta^{18} \mathrm{O}\right)$ vs. salinity for water samples from the Kuiseb Basin.

lower evapo-concentration indicated by more depleted $\delta^{2} \mathrm{H}$ and $\delta^{18} \mathrm{O}$ in groundwater.

The effects of rainfall and evaporation vs. water-rock interaction on groundwater quality can be assessed by examining the relationship between the $\delta^{18} \mathrm{O}\left(\right.$ or $\left.\delta^{2} \mathrm{H}\right)$ and solute concentrations (Winston and Criss, 2002) which in our case is represented by salinity.

We anticipate that if evapo-concentration was responsible for the increase in solute concentrations in groundwater, there should be a positive relationship between the $\delta^{18} \mathrm{O}$ and salinity. Our results show that in the groundwater in the Cuvelai-Etosha Basin, high salinity does not necessarily correspond with high $\delta^{18} \mathrm{O}$ (Fig. 4); Even groundwater with moderate salinity in the Kuiseb Basin is not associated with higher $\delta^{18} \mathrm{O}$ either. The poor relationship between salinity and the $\delta^{18} \mathrm{O}$ is evidence that salinity is mostly due to waterrock interaction or perhaps mixing of fresh groundwater with more saline groundwater.

\subsection{Elemental Composition}

The order of the abundance of cations in the Kuiseb is $\mathrm{Na}>\mathrm{K}>\mathrm{Ca}>\mathrm{Mg}$ and $\mathrm{Na}>\mathrm{Mg}>\mathrm{Ca}>\mathrm{K}$ for Cuvelai-Etosha Basin. The marked differences in relative abundance and absolute concentrations in the major cations is due to differences in basin geology and the extent of water-rock interaction. The order of metal abundance is $\mathrm{Fe}>\mathrm{Al}>\mathrm{V}>\mathrm{As}>\mathrm{Zn}$ for the Kuiseb Basin and $\mathrm{Al}>\mathrm{Fe}>\mathrm{V}>\mathrm{As}>\mathrm{Zn}$ for the Cuvelai-Etosha Basin. We also attribute the major differences in metal composition between the two basins to geology.

We used $\mathrm{Al}$ and As compared to World Health Organisation (WHO) and Water Resources Management Act (Re- 

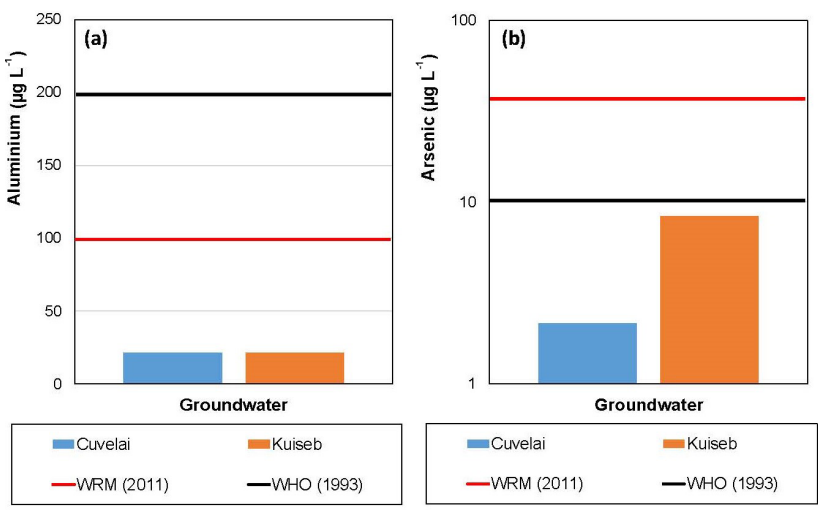

Figure 6. (a) Aluminium and (b) Arsenic levels in the CuvelaiEtosha Basin and Kuiseb Basin. WHO $\rightarrow$ World Health Organisation and WRMA $\rightarrow$ Water Resources Management Act.

public of Namibia, 2013) standards to assess the differences between the groundwater in the Cuvelai-Etosha Basin and Kuiseb Basin (Fig. 6). Aluminium mobility and subsequent transport within the environment is influenced by chemical speciation, hydrological flow paths, water-rock interactions and the composition of the surface and aquifer materials (WHO, 1997). Arsenic in drinking water is a human carcinogen (International Agency for Research on Cancer, 1988). Humans may be exposed to arsenic in water from wells drilled into arsenic-rich ground strata or in water contaminated by industrial or agrochemical waste.

The results of our investigations show that $\mathrm{Al}$ is below the WHO and WRMA standards (Fig. 6a). Arsenic also has lower concentrations in groundwater compared to the WHO and WRMA Standards. Nevertheless, As has higher concentrations in the Kuiseb Basin compared to the Cuvelai-Etosha Basin. The fact that despite the marked differences in the salinity, the As concentration is much higher in the Kuiseb Basin indicates that water-rock interaction is the cause of poor groundwater quality in the Cuvelai-Etosha Basin.

\section{Concluding Remarks}

The groundwater in the Cuvelai-Etosha Basin has poor water quality evidenced by higher groundwater salinity classified as brackish to saline than groundwater in the Kuiseb Basin. There are higher levels of evaporation observed in more enriched stable isotopes of hydrogen and oxygen in groundwater in the Cuvelai-Etosha Basin compared to the Kuiseb Basin. The high salinity in groundwater in the CuvelaiEtosha waters is due to water-rock interaction and less by evapo-concentration and mainly due to water rock interaction in the Kuiseb Basin. The concentration of metals (e.g., As) did not exceed the World Health Organisation and Water Resources Management Act standards which we attribute to water-rock interaction and minimal anthropogenic activities. Data availability. The data for this article
is publicly accessible from ResearchGate -
https://doi.org/10.13140/RG.2.2.33777.58727.

Competing interests. The authors declare that they have no conflict of interest.

Special issue statement. This article is part of the special issue "Understanding spatio-temporal variability of water resources and the implications for IWRM in semi-arid eastern and southern Africa". It is a result of the IAHS Scientific Assembly 2017, Port Elizabeth, South Africa, 10-14 July 2017.

Acknowledgements. The authors acknowledge financial and in-kind support by the UNESCO Chair on Sustainable Water Research for Climate Adaptation in Arid Environment, Gobabeb Training and Research Centre (GTRC), National Council on Research Science and Technology (NCRST) and the Namibia Water Corporation Ltd (NAMWATER).

Edited by: Hodson Makurira

Reviewed by: Tobani Ngonidzashe and two anonymous referees

\section{References}

Christelis, G. and Struckmeier, W. (Eds): Groundwater in Namibia: an explanation to the Hydrogeological Map, 2nd Edition, 132 pp., available at: http://www.bgr.bund.de/EN/Themen/Wasser/ Projekte/abgeschlossen/TZ/Namibia/groundwater_namibia.pdf? _blob=publicationFile (last access: 23 February 2018), January 2011.

Clark, I. D. and Fritz, P.: Environmental isotopes in hydrogeology, CRC press, Boca Raton, Florida, 1997.

Craig, H.: Isotopic variations in meteoric waters, Science, 133, 1702-1703, pmid:17814749, 1961.

Elliot, T.: Environmental tracers, Water Journal, 6, 3264-3269, https://doi.org/10.3390/w6113264, 2014.

Falke, M.: Kuiseb Basin water resources management project, Department of Water Affairs and Forestry, Windhoek, Ministry of Agriculture Water and Forestry, 2008.

Fritz, P., Drimmie, R. J., Frape, S. K., and O'Shea, K.: The isotopic composition of precipitation and groundwater in Canada, in: Isotope Techniques in Water Resources Development, 539551, IAEA, Vienna, Austria, 1987.

Gardiner, M., Matros-Goreses, A., Roberts, C., and Seely, M.: Site Characterisation for Kuiseb Riparian Ecosystems, Desert Research Foundation of Namibia and Gobabeb Training and Research Centre, Windhoek, 2006.

Hamutoko, J. T., Wanke, H., Koeniger, P., Beyer, M., and Gaj, M.: Hydrogeochemical and isotope study of perched aquifers in the Cuvelai-Etosha Basin, Namibia, Isotopes in Environmental and Health Studies, January 2017.

Harbeck, G. E.: Effects of salinity on evaporation. Washington: United States Government Printing Office, available at: 
https://pubs.usgs.gov/pp/0272a/report.pdf (last access: 16 January 2016), 1955.

Heyns, P. and van Vuuren, O.: Hydrology and geohydrology specialist report, in: SAIEA 2010. Strategic Environmental Assessment of the Central Namib Uranium Rush, Unpublished report for the Ministry of Mines and Energy, 2009.

IAEA: Origin of salinity and impacts on fresh groundwater resources: Optimisation of isotopic techniques, Water Resources Programme, Working Materials, 2006.

International Agency for Research on Cancer: Monograph on the carcinogenic risks to humans. Man-Made Mineral fibres and Radon, IARC Scientific Publications, 43, 173-259, 1988.

Kaseke, K. F., Wang, L., Wanke, H., Turewicz, V., and Koeniger, P.: An Analysis of Precipitation Isotope Distributions across Namibia Using Historical Data, PLoS ONE, 11, e0154598, https://doi.org/10.1371/journal.pone.0154598, 2016.

Lewis, F. M. and Walker, G. R.: Assessing the potential for significant and episodic recharge in southwestern Australia using rainfall data, Hydrogeol. J., 10, 229-237, 2002.

McGuire, K. and McDonnel, J.: Stable isotope tracers in watershed hydrology, in: Stable Isotopes in Ecology and Environmental Science, second edition, 334-375, Oxford: Blackwell publishing Ltd., available at: http://udel.edu/ inamdar/BREG667/McGuire_ isotopebook.pdf (last access: 1 March 2018), 2007.

Mendelson, J., Jarvis, A., and Robertson, T.: A profile and atlas of the Cuvelai-Etosha Basin, Windhoek, Raison and Gondwana Collection, 2013.

Miller, R.: Geology of a portion of Central Damaraland, South West Africa/Namibia, South West Africa Series 6, Department of Mines - Geological Survey, Republic of South Africa, 1980.
Msangi, J. P.: Managing water scarcity in Southern Africa: Policy and strategies, in: Combating water scarcity in Southern Africa, 21-41, Springer Netherlands, 2014.

Prada, S., Cruz, J. V., Silva, M. O., and Figueira, C.: Contribution of cloud water to the groundwater recharge in Madeira Island: preliminary isotopic data, 5th International Conference on Fog, Fog Collection and Dew Münster, Germany, FOGDEW2010-97, July 2010.

Pruszkowski, E. and Bosnak, C. P.: The Analysis of Drinking Waters by U.S. EPA Method 200.8 using the NexION 300x/350X ICP-MS in Standard and Collision Modes, Shelton, PerkinElmer, Inc., 2012-2014.

Republic of Namibia: Water Resources Management Act 11 of 2013, Namibia Legal Database, https://laws.parliament.na (last access: 1 March 2018), 2013.

Schneider, G.: The roadside geology of Namibia, Berlin, Gebrüder Borntraeger, 2004.

Turewicz, V.: Stable isotopes of waters in Namibia, Germany, University of Cologne, 2013.

WHO: Aluminium. Geneva, World Health Organization, International Programme on Chemical Safety (Environmental Health Criteria 194), 1997.

Winston, W. E. and Criss, R. E.: Geochemical variations during flash flooding, Meramec River basin, May 2000, J. Hydrol., 265, 149-163, 2002. 